Southern Methodist University

SMU Scholar

Faculty Journal Articles and Book Chapters

Faculty Scholarship

1998

\title{
Treatment alternatives for the dying patient: medical ethics and the law
}

Thomas Wm. Mayo

Southern Methodist University, Dedman School of Law

Robert L. Fine

\section{Recommended Citation}

Thomas Wm. Mayo \& Robert Fine, M.D.,Treatment Alternatives for the Dying Patient: Medical Ethics and the Law, 11 Baylor University Medical Center Proceedings 175 (1998)

This document is brought to you for free and open access by the Faculty Scholarship at SMU Scholar. It has been accepted for inclusion in Faculty Journal Articles and Book Chapters by an authorized administrator of SMU Scholar. For more information, please visit http://digitalrepository.smu.edu. 


\title{
Treatment alternatives for the dying patient: medical ethics and the law
}

\author{
ROBERT L. FINE, MD • Chairperson, Institutional Ethics Committee, BUMC \\ Thomas W. MAYO, JD • Associate Professor of Law, Southern Methodist University
}

Presented at Internal Medicine Grand Rounds, March 31, 1998

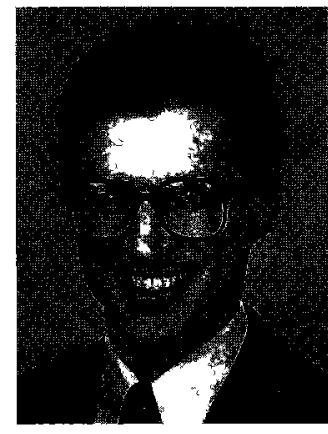

Robert L Fine, $M D$

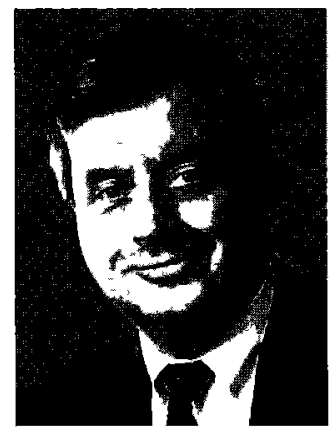

Thomas W Mayo, JD
$\mathrm{D}$ R. ROBERT L. FINE. Professor Thomas Mayo is joining me today to talk about treatment for the dying patient: medical ethics and the law. Tom is an associate professor of law at Southern Methodist University and a scholar in health law and bioethics. He also is an adjunct professor in the Department of Internal Medicine at The University of Texas Southwestern Medical School Tom serves on numerous ethics committees in North Texas. He cochairs the ethics committee of Parkland Memorial Hospital and has served on our own ethics committee for years. $\mathrm{He}$ is a wise teacher and scholar and is well known for his expertise in health law and medical ethics.

When Professor Mayo and I first discussed physician-assisted suicide and euthanasia as part of the spectrum of treatment alternatives for dying patients, we did not know how timely the topic would become. Recently, the first 2 cases of legally sanctioned physician-assisted suicide were reported in Oregon Meanwhile, a rogue respiratory therapist at a California hospital confessed to killing dozens of his patients whom he deemed to be deserving of some type of active euthanasia Of course, $\mathrm{Dr}$ Jack Kevorkıan has etther killed or assisted in the deaths of $>100$ patients.

I want to start by walking you through the poem titled "How Annandale Went Out" (1), written around the turn of the century by the Pulitzer Prize-winning American poet Edwin Arlıngton Robinson (1869-1935). Annandale is a character who appears in several of Robinson's writings In this poem, the speaker, in fact, is a physician.

They called it Annandale - and I was there

To flourish, to find words, and to attend

Liar, physician, hypocrite, and friend,

I watched him, and the sight was not so farr
As one or two that I have seen elsewhere

An apparatus not for me to mend-

A wreck, with hell between him and the end, remained of Annandale, and I was there

I knew the ruin as I knew the man,

So put the two together, if you can,

Remembering the worst you know of me

Now, view yourself as I was, on the spot-

With a slight kind of engine Do you see?

Like this You wouldn't hang me? I thought not

In the first stanza, the physician is very honest about what we physicians sometımes are-sometımes liars, sometımes hypocrites, and sometimes friends to our patients The physician is seeing a patient whom he refers to as an "it," as an "apparatus," as a "wreck," with hell between now and the death to come. Unlike Jack Kevorkian, this physician is saying, "I knew this man when he was well, and I know what he is now" The physician's only weapon against Annandale's impending hellish road to death is a "slight kind of engine"--the cylınder and piston of a syringe When we get to the end of the poem, the physician has euthanized or killed the patient

I would like to put you on the spot and ask how many are willing to hang this physician for his actions? Perhaps hanging is too strong a punishment. How many would at least condemn the physician and say that you are troubled with what he did? The indecision about both the propriety and punishment, if only for the actions described in this poem, reflects our long-standing ambivalence about the alternative of active euthanasia for the dyıng patient And yet, active euthanasia is only one alternative of several we shall explore.

So, what, then, are the options for the dying patient and the physician, nurse, or chaplain "on the spot" with the patient? Obviously, the first is continued aggressive treatment-what I like to refer to as medical practice by technologic imperatıve: "I dialyze, therefore, I am." Medical practıce by technologic ımperative follows the witticism, "To the person who owns a hammer, everything looks like a nal "You just keep pushing the technology at the patient, even when it is no longer beneficial or constructive."

Thankfully, I thınk in American medicıne right now we have evolved to a point where most recognize that there are $1 \mathrm{~lm}$ - 
its to technology. As powerful and seemingly miraculous as it may often be, there comes a point where continuing aggressive treatment is no longer in the best interest of the dying patient. We are relearning to practice with what I call the ethical and the spiritual imperative. We ask not only what can be done techn1cally, but what should be done. By asking the question, we enter an ethical and even a spiritual dimension of healing, and we find that there are 4 basic options that are practiced in this country: passive euthanasia, indirect euthanasia, physician-assisted su1cide, and actıve euthanasia. There remains considerable misunderstanding about these terms; the following are the standard definitions derived from the ethics literature.

Passive euthanasia is termınatıng or withholdıng life-sustaining treatment, thereby allowing the patient to die This is the most traditional way that physicians allow patients to die. It dates back to the Hippocratic tradition 2500 years ago when those physicians recognized that there were times when everything was not possible in medicine, and it was time to withdraw treatment and let nature take its course If you realize that $80 \%$ of the deaths in America occur in health care institutions of some sort, most of them hospitals, and that $80 \%$ of those deaths are preceded by conscious decisions either to withhold or withdraw medical therapy, you realıze how common passive euthanasia has become.

The second option is the practice of indirect euthanasta This is the administering of narcotics or other pharmaceuticals to relieve pain, dyspnea, nausea, or other symptoms of dyıng with the unintended or motdental consequence of death

The third option is physician-assisted suicide. This is the option that has been adopted in the state of Oregon Physicianassisted suicide occurs when the physician provides medications or other interventions with the understanding that the patient intends to use those medications to commit suicide In other words, it is not subtle; it is open and aboveboard. The doctor who prescribes the medication knows exactly what is going to be done with it. Perhaps the strongest proponent of this is the oncologist Dr. Timothy Quill.

Finally, there is active euthanasia - intentionally administering medications or other interventions to cause the patient's death, which is what is going on in the Annandale poem. We know that active euthanasia is not just practiced by fictional physicians but occurs, at least on occasion, in real life as well.

Passive euthanasia and indirect euthanasia have become the standards of practice, for better or worse, in our country when it comes to acknowledging that a patient is going to die and deciding how that is going to occur.

Despite this, there are obvious times when, at least in some people's minds, passive euthanasia and indirect euthanasıa are not optimal or best treatments Clearly, the citizens of the state of Oregon hold this belief. Interestingly, at least a couple of juries who sat in judgment over Dr Jack Kevorkıan believe that passive and indirect euthanasia are not optimal treatments and have refused to condemn him for engagıng in actıve euthanasıa

We are going to explore the alternatives of physician-assisted suicide and active euthanasia in a little more depth. They are obviously not identical, but in both cases the physician intends to kill or and in the killing of a patient who could otherwise be kept alive I will cover the ethical arguments about these, and
Professor Mayo will cover some of the legal issues But first, let me give you some of the historical background.

The ethics of active euthanasia have been debated throughout medical history. In Hippocratic times, active euthanasia was practiced in ancient Greece. The Hippocratic physicians who refused to give a "deadly potion" were actually takıng a minority view Historically, this became the majority view of medicine, yet not without continuous debate.

Sir Thomas More (1478-1535) and Sir Francis Bacon (1561-1626), to name only 2 important Western philosophers, believed that active euthanasia was appropriate for physicians to engage in. Similarly, about 4 centuries later in the USA, there was a bill in the Ohıo legislature to legalıze active euthanasia. The bill was defeated, but the debate did occur To bring us upto-date, in 1997 Oregon passed a bill that officially approved physician-assisted suicide. This bill resembles some of the rules that are in place in the Netherlands pertaining to active euthanasia.

The ethical arguments, etther for or against physicianassisted sucide and active euthanasia, center around autonomy, beneficence, intent and action, and public policy concerns. Autonomy is a key concern in our society It is the notion that each of us ought to be self-governing, we ought to have control over ourselves Proponents of active euthanasia argue that the right to self-governance is absolute and must include the ultimate autonomous act of choosing when and how to die. Around the turn of the century, Eugene Debbs, the social philosopher and labor organizer, stated, "Human life is sacred, but only to the extent that it contributes to the joy and happiness of the one possessing it and to those about him, and it ought to be the privilege of every human being to cross the River Styx in the boat of his own choosing when further human agony cannot be justified by the hope of future health and happiness." (2) Opponents argue that not all voluntary acts are justified by autonomy. John Stuart Mill sard, "it is not freedom to be able to alıenate his freedom" (3) That is, autonomy does not grant one the freedom to give away that freedom Furthermore, as a society we limıt many voluntary acts, including dueling or the voluntary selling of oneself into slavery. Opponents of unlımited autonomy suggest it is not absolute, that we belong either to God or community

Arguments about physician-assisted suicide also center on the concept of beneficence There is the idea that in the practice of medicine we go to the house of the sick for the benefit of the sick. We are there to do good. Proponents of active euthanasia say that, in the face of unmitigated suffering, the most beneficent act is to kill the patient. A duty to practice beneficently, then, can become a duty to kill the suffering patient

As I have looked back through medical histories, perhaps the best example that I have found of the notion of beneficence fulfilled through killing is in the writıngs of Dr. Adina BladySzwajgier in the Warsaw Children's Hospital Dr. Szwajgier was a Viennese-trained pediatrician who completed her residency around 1939. She was picked up by the Nazis and confined to the Warsaw ghetto where she proceeded to establish and run the children's hospital. As you can imagine, they had very little medicine, and periodically Jews were taken out and sent to the kılling camps. 
Late in the war, the remaining Jews in the ghetto revolted against the Nazis and killed several German soldiers At that point, the Nazis came into the ghetto and began shooting and executıng every Jewish person they could find. Dr Szwajgier had already seen German soldiers kill Jewish children by banging their heads against a wall in order to save bullets As the Nazis approached the hospital, she administered sedatives and pain k1llers she had hoarded and actively euthanızed the children on her wards She actually managed to survive but did not publish her memoir I Remember Nothung More untrl she was nearly 80 years old (4). She clearly felt that the unmitigated suffering of her patients demanded something that made her intensely uncomfortable, the killing of her patients. On reading her memoir, I felt that she was acting out of a sense of love for her patients, and that, in telling her story many years later, she was still showing love for her patients

Opponents of beneficence do not accept this argument. They say that the most beneficent act in the face of suffering is, in fact, good palliative care The rare cases of unmitigated suffering do not justify changing medicine's historic rules They basically appeal back to the Hippocratic tradition of refusing to give a deadly potion.

Another ethical argument focuses on intent and action Proponents of active euthanasia and physician-assisted sucide argue that intent and action are unimportant. They say that if passive euthanasia is acceptable, then active euthanasia also must be acceptable, because the end results that count are that the patient is dead and that the patient could not have been kept alive in either case These proponents go on to argue that it is disingenuous for those in support of only passive euthanasia or indirect euthanasia to say that they do not intend for the patient to die when they withdraw treatment or engage in aggressive symptom control to the point of terminal sedation

Opponents of actıve euthanasia and physician-assisted su1cide state that the end results are not nearly as important morally as are intent and action. For example, in our society we draw a distinction between involuntary manslaughter and intentional murder. In both of these cases, obviously the person has died, but the intent was different. When we talk about passive euthanasia and physician-assisted suicide, the intent of passive euthanasia is said to be to relieve suffering by allowing nature to take its course, not to kill the patient. The action engaged in is the withdrawal of treatment that is not really prolonging life so much as prolonging dying. Opponents of active euthanasia and physicianassisted suicide who favor passive and indirect euthanasia argue that when they practice indirect euthanasia, their intent is to relieve suffering by the act of giving only enough medication to relieve that suffering. I can guarantee you that a lot of you who have stood at the bedside of a dying patient, nurses in particular in an intensive care unit setting, have wrestled with this, thinking, "Well, I've got this order for morphine. How much can I give to relieve suffering and yet not engage actively in killing my patient "' It does put nurses, particularly, in an awkward spot

Finally, there are the public policy debates about euthanasia Proponents of active euthanasia and physician-assisted suicide argue that euthanasia happens already but in an unregulated fashIon There are certain polls suggestıng that physicians do, on rare occasions, engage in this process I know that members of the Dallas medical community have, because we have discussed it privately. Proponents argue that it is bad for society to erect false barriers to a practice that is tolerated or endorsed by so many members of the society

Furthermore, proponents of active euthanasia and physicianassisted suicide state that by making these activities legally available, patients will be protected by careful regulation of the practice. This is one of the arguments made in Oregon that I think helped carry that statute through the legislature. They go on to state that patients who might refuse to embark upon certain aggressive treatments for fear of being trapped by the treatment would now know that they have this legal right to engage in active euthanasia or physician-assisted sucide. Moreover, they would have the ability to end therr lives quickly and easily if things did not turn out the way they wanted. Proponents argue that if active euthanasia or physician-assisted suicide were legally avallable, it would empower patients to accept more aggressive treatments than they currently accept

Opponents obviously disagree with everything that I have just said Basically, the public policy opposition to active euthanasıa and physician-assisted suicide falls into what may be called the slippery slope factor That is, if you go over the edge just a little bit, you are going to slide right down the mountain. In 1920, Hoche and Binding published The Permisston to Kill Life Unworthy of Life ("lebens unwertes Leben") (5). It was widely subscribed to by most of organized German medicine, and it convinced the majority of German physicians that there were some human conditions that were so bad, the suffering was so horrible, the disease was so disfiguring, or it caused the patient to be so far beneath what was considered to be human, that it was okay to kill the patient' German physicians and nurses actually murdered several hundred thousand retarded, deformed, demented, and chronically 11 Aryan citizens before they began killing Jews who were seen as socially defective.

Opponents of physician-assisted suicide and active euthanasia who look at the Dutch experience find little hope that the Dutch will behave better than the Germans The Netherlands has tolerated active euthanasia, the intentional administration of a drug by the physician to kill patients, for quite a few years now as long as physicians followed certain safeguards. The safeguards are that the patient has to request active euthanasia repeatedly, the patient has to have unmitigated suffering that cannot be relieved by any other means, and there has to be a second opinion that agrees with the act.

To find out how well this was being practiced, the Dutch government set up a commission under their attorney general, Remelink (6). This commission conducted a prospective study by 405 Dutch physicians who reviewed 5197 deaths. They showed that, on average, there were about 9000 requests for active euthanasia per year in the Netherlands, with about one third of those actually occurring. That $1 \mathrm{~s}$, two thirds of the requests did not lead to an active killing of the patient. The 3000 cases of active euthanasia a year came to $1.8 \%$ of all deaths in the Netherlands Opponents of active euthanasia and physicianassisted suicide note that in $40 \%$ of the Dutch cases, at least 1 of 3 safeguards were violated. It turned out that $84 \%$ of all Dutch 
physıcıans had discussed actıve euthanasıa at least once, and $54 \%$ had participated in it

What would these numbers look like if extrapolated to the United States? Look around this room and ımagine that $>80 \%$ of you would have discussed active euthanasia with your patients and $>50 \%$ would have engaged in tt at least once. There would be about 150,000 requests for active euthanasia a year, with 50,000 actual cases occurring, and, if we were not any better than the Dutch at following the guidelines, there would be 20,000 violations of the proposed safeguards

THOMAS W. MAYO. Obviously, the debate over physicianassisted suicide and active euthanasia has moved out of medical school grand rounds and medical journal settıngs and has become a matter of public debate, public legislation, and public controversy. The public dimension of this debate has not always been

As long as basic respect for the patient's choices is observed, terminating life-sustaining care to the point of terminal sedation does not raise a criminal or civil legal issue in any state.

respectful of the kinds of distinctions that Bob has carefully laid out this morning It has not always been the most well informed of debates, but it has, nonetheless, certainly begun with some vigor, and is not about to get turned around or stopped. I will discuss the form in which some of these public developments have occurred in order to see where the law leaves us on this question in 1998

First, let us start with public opinion. It is often sard that two thirds of Americans support physician-assisted suicide, and it is often said that two thirds of Americans oppose physician-assisted suicide It turns out that both of these propositions are correct It all depends on the question that is being asked and how the choices are framed.

A more careful review of public opinion polling data shows that roughly one third of Americans are against physicianassisted suicide, no matter how one describes it, and regardless of what kinds of safeguards are suggested by way of limitıng this type of euthanasia Another one third of Americans are in favor of physician-assisted suicide as a general proposition and are really quite supportive of $1 \mathrm{t}$.

Then there is a final one third in the middle who are mostly against physician-assisted suicide but who agree that it probably does have some role as a treatment option in certain extreme circumstances This middle group, depending on how the question gets phrased, flips to one side or the other of a yes-or-no chorce when the polling is done.

Let us examine where the states have come out legislatively with regard to these different types of euthanasia Both passive euthanasia and indirect euthanasia (the so-called "double-effect" death) are legal in all 50 states As long as basic respect for the patient's choices is observed, termınating life-sustaining care to the point of terminal sedation does not raise a criminal or civil legal issue in any state Similarly, the American Medical Asso- cration has been pretty influential in the public debate, has been very active in litigation at the US Supreme Court, and has lobbied state and federal legislators extensively The American Medical Association's position is that terminating life support and terminal sedation (or double-effect death) are consistent with its ethical canons.

Physician-assisted suicide, on the other hand, is illegal right now in 48 states, all but Oregon, whose statute we will discuss later, and Massachusetts, which has no statute law on the subject In addition to 48 states, the District of Columbia has banned physician-assisted suicide. The American Medical Association has taken a position consistently over the years that physicianassisted suicide is not permitted under its ethical canons Sim1larly, at the far end of the spectrum, active euthanasia is also not permitted by the Amenican Medical Association's ethical guidelines and would be considered some form of homicide in all 50 states as things currently stand. That is the background for what has become a very interesting legal battle in the courts over the status of prohibitions by the states against physician-assisted su1cide.

To grasp this debate fully, however, it is important to remember a couple of things about litigation in the US Supreme Court on these matters. The very first so-called right-to-die case decided by the Supreme Court only in 1990 was the case of Cruzan ws Director, Missour Department of Health (497 US 261 [1990]). This case involved a young woman, Nancy Beth Cruzan, who, at the time of the commencement of litigation, had been in a persistent vegetatıve state for about 5 years. By the time the case went before the Supreme Court, she had been in a vegetatıve state for nearly 8 years She was in a state facility, and the physicians who worked at that facility opposed the request of her parents that tube feedings be discontinued.

In the state courts, Cruzan vs Director, Missour Department of Health, ended up being litigated all the way to the Missourı Supreme Court. That court imposed a number of quite severe limitations on the right of parents or other surrogate decisionmakers to choose to discontinue life-sustaining treatments in the cases of patients who are unable to speak and choose for themselves The limitations invoked consisted of evidentiary and burden-of-proof rules. The court sand that decision-makers had to show that patients themselves had indicated that they preferred not to have aggressive life-sustaining treatment. Further, this proof had to be shown with clear and convincing evidence, the highest standard of civil proof at trial. Missouri is not the only state that has adopted this position. New York, like a number of other states, is in line with Missour1

The rulıng of the Missourı Supreme Court rased a significant issue: Were some types of severe limitations permissible on a patient's choice (although, in this case, Nancy Beth Cruzan's parents - not the patient - were making the decision) or were these limitations going too far in limiting choices at the end of life? This issue was litigated up to the US Supreme Court

The US Supreme Court was asked to decide whether the US Constitution prevents states from imposing severe procedural evidentiary limitations on family members' end-of-life choices The Supreme Court ruled that there is nothing in the US Constitution that says states cannot impose these fairly extreme 
measures. It sard that, although there may be some outer const1tutional principle that might come into play in a different sort of case, passive euthanasia is primarily a matter of state law, and the states have an extremely free hand and very broad authority to develop their own rules in this area

In addition, in a series of opinions in this case, the Court expressed an almost wistful desire for the increased use of advanced directives, 1 e., living wills or durable powers of attorney for health care Had there been an advanced directive, Cruzan potentially would have been quite a different case, and the failure to respect the advanced directive executed by the patient might well have raised a more acute constitutional question for the Court There is certainly a suggestion in the opinions of 8 of the 9 justices that Cruzan could have come out the other way had there been a living will or a durable power of attorney for health care Moreover, even on the issue of whether state law or federal law governs in this area, the Supreme Court decision was a 5 to 4 decision The Supreme Court was extremely split even over this fairly straightforward proposition.

Just this last term, the Supreme Court had an occasion to consider the legality of prohıbitions against physician-assisted suicide in the cases of Washington ws Glucksburg (117 S. Ct 2303 [1997]), in Washington State, and Vacco vs Qull (117 S Ct 2293 [1997]), in New York Tim Quill, a named pla1ntıff in one of these cases, is one of the most articulate proponents of the position that physician-assisted suicide ought to be regarded as an ethical option In both of these cases, groups of physicians and patients challenged state laws that prohibited physician-assisted sucide across the board In both of these cases, intermediate federal appellate courts, the 9 th Circuit and the 2 nd Circuit, ruled that the prohibitions were unconstitutional. This meant that, as a matter of either substantive due process under the 14th amendment or equal protection under the 14 th amendment, prohibitions like those in Washington and New York were unconstitutional and had to fall.

The impact of these decisions was potentially quite strong, because the 9 th Circuit embraces 9 states, or the entire western part of the USA. The 2 nd Circuit embraces New York, Connect1cut, and Vermont When you add up the populations of these 2 c1rcuits, about one third of the population of the USA lives in states that are covered by the rulings of these 2 intermediate appellate courts It looked as though all of the laws prohibiting physician-assisted suicide in these states, at least, were unconstitutional if these decisions were allowed to stand. Obviously, the Supreme Court would have some interest in clearing up the law in an area that would affect one third of the population of the USA So, the Court granted review in these cases and handed down its opinions last spring

The first part of their holding is probably the most important Just as it did in the Cruzan case, the Court said that states have a wide area of discretion to legislate in accordance with their view of preferred public policy. This authority includes the authority to prohibit physician-assisted suicide, as Washington and New York have done and as Texas did about 2 decades ago. Consequently, the ruling here is that neither the due process clause nor the equal protection clause of the US Constitution limits state choice in this area, at least if the choice is to prohibit physician-assisted suicide.

Other portions of the opinion are worth noting. In one passage, the Supreme Court tried to draw a distinction between passive euthanasia and physician-assisted suicide The argument had been made that, given the involvement of medical personnel in producing the death of a patient, physician-assisted su1cide and passive euthanasia ought to be viewed as roughly the same thing The Court said no, that really is not true as a matter of American law. The Court used both causation and intent to try to show this First, the intent with passive euthanasia is to relieve suffering, not primarily to produce the patient's death, although it may be understood with indirect euthanasia or double-effect that death is a foreseeable but unintended side effect of palliative care The intent, however, is to relieve suffering only and not to achieve death as a means of doing that. In the Court's view, the causative agent with physician-assisted sulcide is a lethal dose of painkiller, whereas the causative agent with indirect euthanasia or double effect is a therapeutic dose of painkiller that was carefully calibrated and delivered to the patient with the intention and design to relieve pain only but turned out to be a dose that was enough to produce the patient's death Again, proponents of physician-assisted suicide see these distinctions as dancing on the head of a pin rather than really making an important distinction, but the Court, a number of the litigants before the Court, and many people in the United States see these distinctions as being absolutely crucial

What is the status of law in Oregon? In 1994, Oregon passed the Death With Dignity Act that provided for physician assistance to the extent of writing a prescription for a dose of medication that will be used to end the patient's life. The voters, by about a $60 \%$ to $40 \%$ margin last November, reaffirmed their desire to have this statute on the books (Oregon Revised Statutes, $\$ \$ 127800-.897$ [1997]). We have now seen the begınnıng of the implementation of that act in Oregon It is important, I think, to understand the safeguards that Oregon has tried to design into this statute.

First, the most important limitation may well be that only competent patients, 1.e., adult patients with decision-making capacity, may participate in this exchange with physicians $\mathrm{M}_{1}$ nors are excluded, as are any adult patients who lack decisionmaking capacity.

Second, this act is limited to patients who have a termınal disease. Although terminal disease is not defined any more precisely than it is under the Natural Death Act in Texas, it has to be determined in accordance with reasonable medical judgment, and 1 t has to be certified by 2 physicians, specifically, the attending physician and a consulting physician who has expertise in a relevant area of medicine

Next, the patient's request has to be repeated over a farly long period of time and has to be repeated, not once, not twice, but 3 times There are 2 oral requests that the statute anticipates, as well as a written one. I will describe those in more detail.

First, there is a 15-day waiting period after the patient's first oral request and before there can be a written request. Fifteen days is also the minımum time between the first oral request and the second. This cooling-off period is intended to give the pa- 
tient, as well as family members and those who are providing care for the patient, an opportunity to work through what it is that has moved the patient to make this request at this time. This request may be a call for help, an indication of the failure, so far, to deal with the pain that he or she is feeling, or an attempt to deal with the loss of dignity that he or she is experiencing. Furthermore, over these 15 days, if there is a way to try to meet some of these objections to the kind of care the patient is receiving, obviously this is the tıme to do it. Second, there is a minımum 2 -day wautıng period between the written request and the written prescription So, the whole process is intended to be slowed down by at least 17 days This is not enough of a slowdown if one is an opponent of physician-assisted suicide. Actually, this 17-day cooling-off period is a point of contention with some proponents of physician-assisted suicide, as well, who think this waiting period is really a denial of the due process rights of patients.

The last couple of safeguards consist of the following: Physicians must ask if they can notify the patient's nearest relatives of the chorce that is being made If the patient says no, the physician may not deny the prescription to the patient on this basis, but it at least has to be discussed. In addition, before writıng the prescription, the physician must offer the patient the opportunity to rescind the choice. This must be explicit and quite affurmatively presented as an option

There also has to be a very detarled informed consent disclosure session with the patient The statute is quite specific and goes on for about a page, which is much longer than most informed consent statutes. All of the things that need to be disclosed with the patient are described, including alternatives to the use of the drug that the patient has requested, a detailed description of what will happen if these drugs are taken in the prescribed dose, and so forth. There is no blinking here in the statute about what is being discussed and what is being done All of that has to be laid out with some care by the physician

In addition, if the physician has a reasonable belief that the patient may be suffering from some kind of psychological or psychiatric condition, e.g., depression, it is mandatory for the physician to order a psychiatric consult. There has to be some attempt at counseling the patient before the rest of the statute can be played out

We will see how long any of these safeguards actually survive over the next few years in the litigious environment of Oregon Frankly, I think that there are quite respectable due process and equal protection arguments that might be made against one or more of the safeguards that have been set out in the statute If that is the case, then obviously the class of patients potentially affected, as well as the class of physicians who will be brought into this, will expand as these limitations drop away.

Frequently over the years, I have heard Bob and a number of other folks on ethics committees around the city talk about choosing the least bad death-deaths that are not that great no matter what choice is made. Therefore, figuring out what is the least bad death, in terms of a patient's own system of values and goals for treatment, is very often all we are left with for discussion purposes It could well be argued that the policy chorce that is being made now or that was made, if you will, by the Supreme
Court last year, is a choice among the least bad alternatives in dealing with physician-assisted suicide and active euthanasia

My colleague Martha Minow, who is at the Harvard Law School, has recently written a review of the Supreme Court cases from last year that I have just discussed (7) As she puts it, there are really 2 big lies we have to choose between In this sense, these are the 2 least bad choices that we are being asked to make The first of these lies is that prohibition will effectively prevent the occurrence of physician-assisted suicide. The fact is, even in a state where it is clearly a felony to engage in this act, as it is in most of the states in this country, the polls published in JAMA and the New England Journal of Medicine, among other places, indicate that there is considerably more activity in this area than is normally publicly acknowledged. Prohıbition may chill people's enthusiasm for it, prohibition may diminish the numbers who are willing to engage in the activity, but it is pretty clear that prohibition will not prevent physician-assisted surcide any more than prohibition statutes have ever prevented entirely the act they address

The second lie Professor Minow alludes to in her article is the lie that the legalization of physician-assisted suicide would not systematically and routinely be used to push dying people into death. She is not talking necessarily about the "slippery slope" here I think what she is talking about is that the legalization of physician-assisted suicide in any legal system, whether it is the legal system of Texas, or California, or the USA as a whole, changes the terms and conditions of the care that is provided at the end of life, and that affects everybody. She puts it this way: "Exits change what it means to be here The right to terminate treatment makes contınuing treatment a dally choice The right to terminate a pregnancy makes contınuing the pregnancy a deliberate act The right to divorce makes maintaining a marriage a matter of volition. The right to the ard of a doctor in ending one's life means that dying patients will be invited to think about its exercise It means that family members will consider it. It means that hospitals and nursing homes will institutionalize it. It means that popular culture will elaborate it. It means that young and vibrant people will contemplate it." Her position is that the Supreme Court, although it did not articulate these 2 positions as 2 lies to choose between, in fact, did choose one of these when it said that prohibitions against physician-assisted suicide are constitutional. The public policy choice that we are looking at over the next 5 to 15 years in every state in the country will be which of these positions is the least unappealing to those who are in a position to make the choice

DR. FINE: I want to wrap up with what, I hope, are some pragmatic truths about being on the spot with the dying patient I am going to draw on a very nice article written by Dr. Andrew Billings and Dr Susan Block (8) They outlıne for us a comprehensive assessment of the dying patient that takes in account not only the physical symptoms such as pain, nausea, weakness, and dyspnea, but also social, psychological, and spiritual factors Untreated pain is a common precursor to suicide attempts in our society. We know from the Dutch experience that when pain was the reason why Dutch citizens were requesting active euthanasia and it was effectively treated, the request for active euthana- 
sia was withdrawn. Unfortunately we have a long way to go The SUPPORT study in this country revealed that half of dyıng pat1ents experience poorly treated pain near death (9) In my own experience workıng as your ethics consultant here, I frequently find that patients and their families doubt our ability to treat pain and other symptoms of dying They think that we cannot do $1 \mathrm{t}$ ! Sometımes, this causes them to seek early termination of treatment If we can reassure patients that their pain can be managed, that their symptoms can be taken care of, many will choose to continue life-sustaining treatment and have a chance to get better. I think it is important that we reassure our patients of both the avallability and our ability to treat their pain and other symptoms.

We also must assess and deal with the psychological issues of dying, including grief, depression, and anxiety. This is easier said than done Obviously, one of the biggest problems we face is that many of the vegetative symptoms of depression-malaise, fatigue, and so on-are the symptoms of innumerable terminal illnesses Sometimes the only way you, as a physician, are going to know if a patient is suffering with depression is to consult with a psychiatrist or psychologist. Often, we must try empiric treatment with antidepressants to determine if the vegetative symptoms will improve.

Dealing with spiritual and values issues is also important The old adage that there are no atheists in foxholes rings true for dyıng patients as well. American society is a religious society Constder asking the FICA questions of your patients Do you have a religious or spiritual farth? What is the involvement of that faith in your life? Do you have a religious or spiritual community? How do you want to me to address your religious or spiritual concerns? Only by asking these questions do you have a chance to deal with them. Your patients and their families will often guide you through this process in their spiritual life if you give them a chance At Baylor Unıversity Medical Center, we are fortunate to have the additional expertise of skilled hospital chaplains.

Frequently, we must assess and deal with difficulties in interpersonal relationships. As health care professionals, we are all familiar with dysfunctional families, and the dysfunctional may only get worse in the face of terminal illness Terminal illnesses sometimes bing out the best within families, but they also may bring out some pretty unusual and difficult coping mechanisms withın families. We need to recognize these and try to deal with them as best as we can. Again, I think this is where a mult1disciplinary team approach comes in, with social workers and chaplains becoming important adjuncts to the overall treatment effort

Finally, I would like for you to reflect with me on the nature of the physician-patient relationship. The Jewish philosopher Martin Buber suggests to us in his most famous work, I and Thou, that there are 2 fundamental relationships (10). One is the "I-1t" relationship. When we see patients in an I-1t relationship, we come to view them as just objects to be manipulated in the environment. When we talk in an I-1t relationship, we often go back to those technical questions that are drummed into our heads in training, and the conversation often is something like, "Can you tell me what the potassium, the blood gas, and the complete blood count are on the pneumonia in bed 12 "' The information is necessary, but it is not sufficient for the best management of the dying patient This conversation reflects the loss of the unique humanity of the person with pneumonia

Buber suggests that a more appropriate relationship is an "Ithou" relationship It is a relationshıp of coequals based upon mutual respect, mutual trust, and even mutual need. I think that in order to create an I-thou relationship in the clinical setting of the dying patient, the physician has to be willing to have a different kind of conversation that, I am afraid, does not happen as often as it should. Often, when I go in the role of ethics consultant in an effort to work through some percerved problem or crisis around a dying patient, one of the questions that I will ask the patıent is something along the lines of, "I know it's diff1cult to talk about this, but would you like to talk about the sertousness of your 1 llness and even the possibility of death?" Most

When we finally accept that death is not our worst enemy, we can begin to see death as a healing of sorts. Death is, after all, inevitable and inescapable.

patients say yes Almost inevitably, the response I get from patients is, "Why, Dr. Fine, nobody has ever asked me that before." This indicates to me that none of the doctors and none of the nurses have asked the patient that before. I will ask if it bothers him or her that I have asked. Almost all welcome the discussion, which then leads to questions such as, "Where do you want to be when you die?", "Who should be there?",, or "In your worst moments, have you wished your death might come sooner?" This begins to open up the relationship with the patient and moves it beyond the I-it technical necessitres (e $g$, knowing the potassium, the blood gas, and the complete blood count). The relationship becomes a more spiritual and loving I-thou that is essential to the highest quality of healing!

Remember that there is more than one type of healing. When we finally accept that death is not our worst enemy, we can begin to see death as a healıng of sorts Death is, after all, inevitable and inescapable.

On that note, I want to end with a little tale that Victor Frankl wrote of in Man's Search for Meaning (11). Victor Frankl recalled a Persian folk tale involving a wealthy man and his servant They are walking through the garden of the wealthy man, and the servant is walking ahead Suddenly, the servant comes upon the figure of Death. Startled and frightened out of his wits, the servant turns and runs as fast as he can the other way and gets back to his master. He says, "Master, I have just seen Death in the garden, and he has come to take me. Please, I have been such a farthful servant, may I have your fastest horse so that I might escape and run away" The master says, "Certainly you may. Take my fastest horse and flee to Teheran at once." And so the servant does. The master continues walking through the garden, and he, too, comes upon Death, but, being a very brave man and, frankly, a little bit angry at this point, he looks Death right in the eye He confronts Death, and he says, "Death, why did you scare away my trusted and loyal servant? He has done 
you no wrong. Surely, it is not his time to die." To this, Death replies, "I did not mean to scare him so. I was only surprised to find him here in the garden today when I planned to meet him in Teheran tonight"

\section{References}

1 Robinson EA The Town Down the River A Book of Poems New York Charles Scribner's Sons, 1910 93-94

2 Robinson V A symposium on euthanasia Medical Rerrew 1913,19 143-157

3 Mill JS On Liberty Indianapolss, Ind Hackett Publishing, 1978

4 Blady-Szwajgier A I Remember Nothing More The Warsaw Children's Hospital and the Jewish Resistance New York Pantheon Books, 1990
5 Lifton RJ The Nazi Doctors Medical Kulling and the Psychology of Genocide New York Bastc Books, 1986

6 Remelınk Commission Report Health Policy 1992,22(special issue) 1-262

7 Minow M Which question' Which he? Reflections on the physician-assisted suicide cases In Hutchinson DJ, Strauss DA, Stone G, eds Supreme Court Revrew 1997 Chicago University of Chicago Press, 1998 1-30

8 Block SD, Bilings JA Patient requests to hasten death evaluation and management in terminal care Arch Intern Med 1994,154 2039-2047

9 SUPPORT principal investigators A controlled trial to improve care for seriously ill hospitalized patients the study to understand prognoses and preferences for outcomes and risks of treatments JAMA 1995,274 1591-1598

10 Buber M I and Thou New York Scribner, 1970

11 Frankl VE Man's Search for Meaning, revised ed New York Washıngton Square Press, 1985

\section{Acknowledgment of contributors}

Our thanks and appreciation to the following individuals who contributed to the BUMC Proceedings Fund from June 5, 1998, to August 28, 1998:

Blarr, Drury, MD

Campbell, Robert D., MD

Kitchens, Jr., Lloyd W., MD
Klıntmalm, Goran, $\mathrm{MD}, \mathrm{PhD}$

Kuhn, Joseph A , MD

Lane, B. Ward, MD
Peters, George N., MD

Ware, Jr., Elgin W., MD 